\title{
Sesquiterpenes and other constituents of Xylaria sp. NC1214, a fungal endophyte of the moss Hypnum sp.
}

Han $\mathrm{Wei}^{\mathrm{a}, 1}$, Ya-ming $\mathrm{Xu}^{\mathrm{a}}$, Patricia Espinosa-Artiles ${ }^{\mathrm{a}}$, Manping X. Liu ${ }^{\mathrm{a}}$, Jiang-Guang Luo ${ }^{\mathrm{a}, \mathrm{b}}$, Jana M. $\mathrm{U}^{\prime} \operatorname{Ren}^{\mathrm{c}}$, A. Elizabeth Arnold ${ }^{\mathrm{c}, \mathrm{d}}$, and A. A. Leslie Gunatilaka ${ }^{\mathrm{a} *}$

${ }^{a}$ Southwest Center for Natural Products Research and Commercialization, School of Natural Resources and the Environment, College of Agriculture and Life Sciences, The University of Arizona, 250 E. Valencia Road, Tucson, Arizona 85706, United States

${ }^{\mathrm{b}}$ State Key Laboratory of Natural Medicines, Department of Natural Medicinal Chemistry, China Pharmaceutical University, 24 Tong Jia Xiang, Nanjing 210009, P. R. China

${ }^{\mathrm{c}}$ School of Plant Sciences, College of Agriculture and Life Sciences, The University of Arizona, Tucson, Arizona 85721, United States

${ }^{\mathrm{d}}$ Department of Ecology and Evolutionary Biology, The University of Arizona, Tucson, Arizona 85721, United States

* Corresponding author.

E-mail address: leslieg1 @email.arizona.edu.

${ }^{1}$ Current address: Department of Pharmacy, The First Affiliated Hospital, Zhengzhou University, Zhengzhou 450052, P. R. China.

\begin{abstract}
Oxygenated guaiane-type sesquiterpenes, xylaguaianols A-D (1-4), an iso-cadinane-type sesquiterpene
\end{abstract}


isocadinanol A (5), and an $\alpha$-pyrone 9-hydroxyxylarone (6), together with five known sesquiterpenes (7-11), and four known cytochalasins (12-15) were isolated from a culture broth of Xylaria sp. NC1214, a fungal endophyte of the moss Hypnum sp. The structures of all compounds were elucidated by the analysis of their spectroscopic data and relative configurations of $\mathbf{1}-\mathbf{5}$ were determined with the help of NMR NOESY experiments. Cytochalasins C (12), D (13), and Q (14) were investigated for their cytotoxic activity against five tumor cell lines. Cytochalasin D showed significant cytotoxicity against all five cell lines, with $\mathrm{IC}_{50} \mathrm{~S}$ ranging from 0.22 to $1.44 \mu \mathrm{M}$, whereas cytochalasins $\mathrm{C}$ and $\mathrm{Q}$ exhibited moderate, but selective cytotoxicity.

Keywords: Xylaria sp., fungal endophyte, Hypnum sp., xylaguaianols, sesquiterpenes, $\alpha$-pyrone, cytochalasins 
Endophytic fungi constitute rich sources of secondary metabolites with novel structures and biomedical potential (Schulz et al., 2002; Gunatilaka, 2006: Zhang et al., 2006). Xylaria species, often isolated as endophytes from decaying plant tissue, occur worldwide from arctic to tropical regions (Schu $\square$ ffler et al, 2007). Many Xylaria species are known to produce diverse secondary metabolites (Song et al., 2014), which include succinic acid derivatives (Klaiklay et al., 2012), cytochalasins (Espada et al., 1997), $\alpha$-pyrones (Schu $\square$ ffler et al., 2007), terpenoids (Li et al., 2010; Wu et al., 2014; Yan et al., 2011), xanthones (Davis and Pierens, 2006; Healy et al., 2004), cyclopeptides (Lin et al., 2001; Wu et al., 2011), and lactones (Jimenez-Romero et al., 2008). In an ongoing search for bioactive natural products from fungal endophytes, a cytotoxic EtOAc extract of Xylaria sp. NC1214, a fungal endophyte of the moss Hypnum sp., cultured in potato dextrose broth (PDB) containing $0.25 \mathrm{mM} \mathrm{CuSO}_{4}(\mathrm{Paranagama} \mathrm{et}$ al., 2007) was investigated. Fractionation of this extract resulted in the isolation of fifteen metabolites including four cytotoxic cytochalasins. Herein reported are the isolation and structure elucidation of four new oxygenated guaiane-type sesquiterpenes (1-4), a rare bicyclic sesquiterpene (5) and a new $\alpha$-pyrone (6), as well as the known sesquiterpenes, epi-guaidiol A (7) (Xu et al., 2009), hydroheptelidic acid (8) (Calhoun et al., 1992), gliocladic acid (9) (Itoh et al., 1982), bullatantriol (10) (Sung et al., 1992), and 1 $\beta, 4 \beta, 7 \alpha$-trihydroxyeudesmane (11) (Sung et al., 1992), and four known cytochalasins, cytochalasins C (12), D (13), Q (14), and R (15) (Edwards et al., 1989). Also reported herein is the cytotoxic activity of cytochalasins 12-14 against five sentinel cancer cell lines.

\section{Results and discussion}

Xylaguaianols A (1) and B (2) (Figure 1) were determined to have the same molecular formula, $\mathrm{C}_{15} \mathrm{H}_{28} \mathrm{O}_{4}$, on the basis of their HRMS and ${ }^{13} \mathrm{C}$ NMR spectroscopic data, indicating that they are sesquiterpenes. Comparison of their ${ }^{1} \mathrm{H}$ and ${ }^{13} \mathrm{C}$ NMR spectroscopic data (Tables 1 and 2, respectively) with those reported for bicyclic sesquiterpenes (Wu et al., 2014) suggested that $\mathbf{1}$ and $\mathbf{2}$ are tetrahydroxy derivatives of guaiane-type sesquiterpenes. The ${ }^{13} \mathrm{C}$ and DEPT NMR spectra of xylaguaianol A (1) (Table 
2) indicated fifteen carbons consisting of three primary, six secondary (of which one was oxygenated; $\delta_{\mathrm{C}}$ $68.8)$, three tertiary, and three oxygenated quaternary carbons $\left(\delta_{\mathrm{C}} 75.3,77.6\right.$ and 81.9$)$. The analysis of the ${ }^{1} \mathrm{H}$ NMR and HSQC data (Table 1$)$ established that 1 possessed three tertiary methyl groups $\left(\delta_{\mathrm{H}} 1.08 \mathrm{~s}, \delta_{\mathrm{C}}\right.$ $\left.33.3 ; \delta_{\mathrm{H}} 1.18 \mathrm{~s}, \delta_{\mathrm{C}} 24.5 ; \delta_{\mathrm{H}} 1.25 \mathrm{~s}, \delta_{\mathrm{C}} 26.6\right)$, six methylene groups of which one is oxygenated $\left(\delta_{\mathrm{H}} 3.28-3.33\right.$ $\mathrm{m}$ and $\left.3.59-3.65 \mathrm{~m}, \delta_{\mathrm{C}} 68.8\right)$, and three methine groups $\left(\delta_{\mathrm{H}} 1.95 \mathrm{~m}, \delta_{\mathrm{C}} 33.4 ; \delta_{\mathrm{H}} 2.17 \mathrm{~m}, \delta_{\mathrm{C}} 49.3 ; \delta_{\mathrm{H}} 2.86 \mathrm{~m}\right.$, $\delta_{\mathrm{c}}$ 55.0). Detailed analysis of ${ }^{1} \mathrm{H}-{ }^{1} \mathrm{H}$ COSY and HMBC spectra (Figure 2) confirmed that 1 contained a guaiane-type sesquiterpene skeleton bearing four hydroxyl groups. Careful inspection of the HMBC spectrum suggested the presence of long-range correlations of $\mathrm{H}-15$ to $\mathrm{C}-4\left(\delta_{\mathrm{C}} 81.9\right), \mathrm{H}-14$ to $\mathrm{C}-10\left(\delta_{\mathrm{C}}\right.$ 75.3), H-13 to C-11 ( $\left.\delta_{\mathrm{C}} 77.6\right)$, and $\mathrm{H}-13$ to $\mathrm{C}-12\left(\delta_{\mathrm{C}} 68.8\right)$ confirming that these four hydroxyls were attached to C-4, C-10, C-11 and C-12. These data indicated that $\mathbf{1}$ had the same overall skeletal structure as that of $4 \beta$-hydroxyxylaranol recently encountered in an endophytic fungus of a mangrove plant (Zeng et al., 2015). However, comparison of their $[\alpha]_{\mathrm{D}}$ and NMR data suggested that they are not identical but may be stereoisomers. The relative configuration of $\mathbf{1}$ was assigned by the NOESY experiment combined with MM2 energy-minimized three-dimensional molecular modeling. The NOE correlations of $\mathrm{H}-1$ with $\mathrm{H}-5 / \mathrm{H}-$ 14, and H-5 with $\mathrm{H}-14 / \mathrm{H}-15$ established that they are on the same face of the molecule (Figure 3). Additional NOEs were observed between $\mathrm{H}-6 \alpha$ and 4-OH/H-12/H-13, indicating that the protons at C-6 2 , C-12 and C-13 as well as the hydroxyl at C-4 were on the same side of the ring system. Thus, the structure of xylaguaianol A was established as pseudo- $1 \beta, 5 \beta, 7 \beta(\mathrm{H})$-guaiane- $4 \alpha, 10 \alpha, 11,12$-tetraol (1). The stereoconfiguration at C-11 of 1 was defined by comparison with the data for xylaguaianol B (2) as described below.

Analysis of the ${ }^{1} \mathrm{H}$ (Table 1), ${ }^{13} \mathrm{C}$ (Table 2) and 2D NMR data of xylaguaianol B (2) suggested that it shared similar structural features with those of 1. In addition, the NOESY data of 2 indicated that its bicyclic ring system had the same relative configuration as in $\mathbf{1}$. Careful comparison of the ${ }^{13} \mathrm{C} N M R$ chemical shifts of $\mathbf{1}$ and $\mathbf{2}$ suggested that the major differences between these existed at C-7 $\left(\delta_{\mathrm{C}} 33.4\right.$ for $\mathbf{1}$, $\delta_{\mathrm{C}} 32.2$ for 2$), \mathrm{C}-12\left(\delta_{\mathrm{C}} 68.8\right.$ for $\mathbf{1}, \delta_{\mathrm{C}} 70.2$ for 2$)$ and $\mathrm{C}-13\left(\delta_{\mathrm{C}} 26.6\right.$ for $\mathbf{1}, \delta_{\mathrm{C}} 23.8$ for 2$)$, indicating that 1 
and 2 were a pair of epimers of $R / S$ configurations at $\mathrm{C}-11$. Careful examination of the ${ }^{1} \mathrm{H}$ and ${ }^{13} \mathrm{C}$ NMR data recently reported for a series of guaiane-type sesquiterpenes epimeric at C-11, whose absolute configurations have been determined by X-ray crystallographic analysis (Wu et al., 2014), suggested that the ${ }^{13} \mathrm{C}$ NMR data may be used to define the absolute stereochemistry at $\mathrm{C}-11$ for this type of sesquiterpenes. The reported data indicated that the $\gamma$-gauche interaction (Whitesell et al., 1987) between C-6/C-8 and 11-OH/C-12/C-13 resulted in the difference of chemical shifts for these carbons, especially for $\mathrm{C}-13$. The $7 R / 11 R$ epimer always exhibited $\delta_{\mathrm{C}}$ for $\mathrm{C}-13$ at a higher field compared to that of the corresponding $7 R / 11 S$ epimer. It was found that the $\delta_{\mathrm{C}}$ for C-13 of $2(23.8)$ was at a higher field than that of $\mathbf{1}$ (26.6) and this allowed us to distinguish the $11 R^{*}$ and $11 S^{*}$ configurations for $\mathbf{1}$ and $\mathbf{2}$, respectively, by assuming $7 S^{*}$-configuration of $\mathbf{1}$ and $\mathbf{2}$. Thus, xylaguaianol A and xylaguaianol $\mathrm{B}$ were identified as $1 \beta, 5 \beta, 7 \beta(\mathrm{H})$-guaiane- $4 \alpha, 10 \alpha, 11 R^{*}, 12$-tetraol (1) and $1 \beta, 5 \beta, 7 \beta(\mathrm{H})$-guaiane- $4 \alpha, 10 \alpha, 11 S^{*}, 12$-tetraol (2), respectively.

Xylaguaianol C (3), obtained as a colorless oil, was determined to have the molecular formula $\mathrm{C}_{15} \mathrm{H}_{28} \mathrm{O}_{3}$ by HRESIMS and NMR data, suggesting two degrees of unsaturation. The ${ }^{13} \mathrm{C}$ NMR data (Table 2) established the presence of fifteen $\mathrm{sp}^{3}$ carbons of which three were oxygenated $\left(\delta_{\mathrm{C}} 69.2,74.0,75.9\right)$. Further analysis of the ${ }^{1} \mathrm{H}$ (Table 1 ), ${ }^{13} \mathrm{C}$ (Table 2), and ${ }^{1} \mathrm{H}^{-1} \mathrm{H}$ COSY NMR data together with its molecular formula suggested the presence of a trihydroxylated guaiane-type sesquiterpene skeleton in $\mathbf{3}$. The HMBC correlations of $\mathrm{H}-13$ to $\mathrm{C}-11$ and $\mathrm{C}-12$, and $\mathrm{H}-14$ to $\mathrm{C}-10$ confirmed that three of these hydroxyls were located at C-10, C-11 and C-12. The NOESY correlations of H-1 with H-14/H-5 and H-5 with $\mathrm{H}-15$ indicated that these protons were co-facial. Additional correlations of $\mathrm{H}-8 \alpha$ with $\mathrm{H}-12 / \mathrm{H}-13$ were also observed, suggesting that these protons were on the same side of the guaiane-ring. However, with the data available it was not possible to define the configuration at $\mathrm{C}-11$ of $\mathbf{3}$, and because attempted crystallization failed, X-ray crystallography could not be applied for this purpose. Thus, the structure xylaguaianol $\mathrm{C}$ was determined as $1 \beta, 4 \alpha, 5 \beta, 7 \beta(\mathrm{H})$-guaiane-10 $\alpha, 11,12$-triol (3).

Xylaguaianol D (4), obtained as a colorless oil, was assigned the molecular formula $\mathrm{C}_{15} \mathrm{H}_{26} \mathrm{O}_{2}$ by a 
combination of HRESIMS and NMR data, suggesting three degrees of unsaturation. The ${ }^{13} \mathrm{C}$ NMR data of 4 (Table 2) demonstrated the presence of fifteen signals consisting of thirteen $\mathrm{sp}^{3}$ carbons including two oxygenated $\left(\delta_{\mathrm{C}} 69.0\right.$ and 75.2$)$ and two quaternary sp ${ }^{2}$ carbons $\left(\delta_{\mathrm{C}} 129.7\right.$ and 142.0). Comparison of the ${ }^{1} \mathrm{H}$ and ${ }^{13} \mathrm{C}$ NMR data of $\mathbf{4}$ (Tables 1 and 2, respectively) with those of $\mathbf{1}-\mathbf{3}$ combined with its ${ }^{1} \mathrm{H}^{-1} \mathrm{H}$ COSY data established the presence of a double bond bearing guaiane-type sesquiterpene ring system in 4 . This double bond was located between $\mathrm{C}-1$ and $\mathrm{C}-10$ based on strong HMBC correlations observed for methyl protons at $\delta 1.63(\mathrm{H}-14)$ and two olefinic carbons at $\delta_{\mathrm{C}} 129.7(\mathrm{C}-1)$ and $142.0(\mathrm{C}-10)$ (Figure 2). The NOE correlations of $\mathrm{H}-4$ with $\mathrm{H}-5$ and $\mathrm{H}-6 \alpha$ with $\mathrm{H}-15 / \mathrm{H}-12$ suggested that these protons are on the same side of the molecule. Thus, xylaguaianol $\mathrm{D}$ was identified as $4 \beta, 5 \beta, 7 \beta(\mathrm{H})-1,10$-dehydroxyguaiane-11,12-diol (4).

Isocadinanol A (5), obtained as a colorless oil, was determined to have the molecular formula $\mathrm{C}_{15} \mathrm{H}_{26} \mathrm{O}_{3}$ by its HRESIMS and NMR data, suggesting three degrees of unsaturation. The ${ }^{13} \mathrm{C}$ NMR spectrum of 5 revealed the presence of fifteen carbons suggesting that it was a sesquiterpene. Analysis of ${ }^{1} \mathrm{H}$ and HSQC NMR data indicated that 5 possessed a tertiary methyl $\left(\delta_{\mathrm{H}} 1.31 \mathrm{~s}, \delta_{\mathrm{C}} 27.8\right)$, three secondary methyls $\left[\delta_{\mathrm{H}} 0.86 \mathrm{~d}(J=6.4 \mathrm{~Hz}), \delta_{\mathrm{C}} 21.0 ; \delta_{\mathrm{H}} 0.97 \mathrm{~d}(J=6.8 \mathrm{~Hz}), \delta_{\mathrm{C}} 21.2 ; \delta_{\mathrm{H}} 1.05 \mathrm{~d}(J=6.4 \mathrm{~Hz}), \delta_{\mathrm{C}} 14.9\right]$, three methylenes $\left[\delta_{\mathrm{H}} 1.08 \mathrm{~m}\right.$ and $1.54 \mathrm{~m}, \delta_{\mathrm{C}} 19.7 ; \delta_{\mathrm{H}} 1.13 \mathrm{~m}$ and $1.67 \mathrm{~m}, \delta_{\mathrm{C}} 37.2 ; \delta_{\mathrm{H}} 1.66 \mathrm{~m}$ and $2.12 \mathrm{ddd}(J$ $\left.=13.2,4.4,2.4 \mathrm{~Hz}), \delta_{\mathrm{C}} 34.8\right]$, and six methines of which two were oxygenated $\left[\delta_{\mathrm{H}} 2.92 \mathrm{dd}(J=16.0,1.6\right.$ $\left.\mathrm{Hz}), \delta_{\mathrm{C}} 68.3 ; \delta_{\mathrm{H}} 3.43 \mathrm{~m}, \delta_{\mathrm{C}} 71.3\right]$. These data also indicated that 5 contained two oxygenated quaternary carbons of an oxirane moiety $\left(\begin{array}{llll}\delta_{\mathrm{C}} & 65.9 & \text { and } 66.4\end{array}\right)$. The presence of the fragments $\mathrm{CH}\left(\mathrm{CH}_{3}\right) \mathrm{CH}(\mathrm{O}) \mathrm{CH}_{2} \mathrm{CHCH}\left(\mathrm{CH}_{3}\right)_{2}$ and $-\mathrm{CH}(\mathrm{O}) \mathrm{CH}_{2} \mathrm{CH}_{2} \mathrm{CH}-$ in 5 was deduced by the analysis of its ${ }^{1} \mathrm{H}-{ }^{1} \mathrm{H}$ COSY data and the connectivity between these two fragments and with the two epoxy quaternary carbons and a tertiary methyl was established by the analysis of its HMBC data (Figure 2). These data suggested that 5 contained an isocadinane ring derived from a cadinane-like ring system in which the methyl group at C-4 has undergone rearrangement to C-5. The relative configuration of 5 was determined based on its NOESY spectrum combined with MM2 energy-minimized three-dimensional molecular modeling. The 
NOE correlation of H-1 with H-10 confirmed that these had the same relative configuration. Additional NOEs observed between $\mathrm{H}-9 / \mathrm{H}-14, \mathrm{H}-14 / \mathrm{H}-4, \mathrm{H}-4 / \mathrm{H}-15$, and $\mathrm{H}-15 / \mathrm{H}-7$ (Figure 3) indicated that $\mathrm{H}-1$, hydroxyls at C-4 and C-9, the C-5(6) epoxy group and the isopropyl group at C-7 were all on the same side of the ring system. Thus, the structure of isocadinanol A was established as $1 \alpha, 7 \beta, 10 \alpha(\mathrm{H})-5 \alpha(6 \alpha)$-epoxyisocadinane- $4 \alpha, 9 \alpha$-diol (5).

9-Hydroxyxylarone (6), obtained as a white amorphous solid, was assigned the molecular formula $\mathrm{C}_{13} \mathrm{H}_{18} \mathrm{O}_{4}$ by a combination of HRESIMS and NMR data, indicating five degrees of unsaturation. Inspection of its ${ }^{1} \mathrm{H},{ }^{13} \mathrm{C}$ and $\mathrm{HMBC}$ NMR data suggested the presence of thirteen carbons consisting of four methyl carbons of which one was oxygenated, one methylene carbon, three methine carbons of which two were aromatic and/or olefinic and five $\mathrm{sp}^{2}$ quaternary carbons. Analysis of ${ }^{1} \mathrm{H}$ NMR and HSQC data demonstrated the presence of three tertiary methyls of which one was oxygenated $\left(\delta_{\mathrm{H}} 1.93 \mathrm{~s}, \delta_{\mathrm{C}} 8.7 ; \delta_{\mathrm{H}} 1.94\right.$ $\left.\mathrm{s}, \delta_{\mathrm{C}} 13.0 ; \delta_{\mathrm{H}} 3.90 \mathrm{~s}, \delta_{\mathrm{C}} 56.2\right)$, one secondary methyl $\left[\delta_{\mathrm{H}} 0.92 \mathrm{t}(J=7.2 \mathrm{~Hz}), \delta_{\mathrm{C}} 9.6\right]$, one methylene $\left(\delta_{\mathrm{H}}\right.$ $\left.1.55-1.75 \mathrm{~m}, \delta_{\mathrm{C}} 30.4\right)$ and three methines $\left[\delta_{\mathrm{H}} 4.43 \mathrm{dt}(J=8.6,6.6 \mathrm{~Hz}), \delta_{\mathrm{C}} 70.0 ; \delta_{\mathrm{H}} 6.18 \mathrm{~s}, \delta_{\mathrm{C}} 92.9 ; \delta_{\mathrm{H}} 6.49\right.$ dd $\left.(J=8.8,1.2 \mathrm{~Hz}), \delta_{\mathrm{C}} 135.8\right]$. Further analysis of the HMBC spectrum (Figure 2) indicated the existence of an $\alpha$-pyrone system in 6 and comparison of the ${ }^{1} \mathrm{H}$ and ${ }^{13} \mathrm{C}$ NMR data of 6 with the known $\alpha$-pyrone, xylarone (Schüffler et al., 2007), established that they were structurally related, except for the presence of an oxymethine moiety $\left(\delta_{\mathrm{H}} 4.43 \mathrm{~m}, \delta_{\mathrm{C}} 70.0\right)$ in 6 instead of the methylene moiety in xylarone. These findings together with HRMS data suggested that $\mathbf{6}$ was a hydroxylated derivative of xylarone. The HMBC correlations of H-10 and H-11 to C-9 and H-9 to C-7 and C-8 suggested that this hydroxyl group was at C9. However, lack of sufficient material precluded us from performing additional studies to determine its configuration. Thus, the structure of this metabolite was elucidated as 9-hydroxyxylarone (6).

Metabolites 7-15 were identified as epi-guaidiol A (7) (Xu et al., 2009), hydroheptelidic acid (8) (Calhoun et al., 1992), gliocladic acid (9) (Itoh et al., 1982), bullatantriol (10) (Sung et al., 1992),

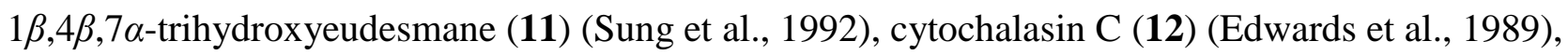
cytochalasin D (13) (Edwards et al., 1989), cytochalasin Q (14) (Edwards et al., 1989), and cytochalasin R 
(15) (Edwards et al., 1989), respectively, by comparison of their MS and NMR spectroscopic data with those reported. Since many cytochalasins have been reported to be cytotoxic (Van Goietsenoven et al., 2011; Xu et al., 2015), cytochalasins C (12), D (13) and Q (14) encountered in this study were tested against a panel of five human tumor cell lines including prostate adenocarcinoma (PC-3M), non-small cell lung cancer (NCI-H460), CNS glioma (SF-268), breast adenocarcinoma (MCF-7), and metastatic breast adenocarcinoma (MDA-MB-231). As depicted in Table 3, cytochalasin D (13) exhibited strong cytotoxicity against all five cell lines with moderate selectivity to NCI-H460. Cytochalasins C (12) and Q (14) showed moderate cytotoxicity against all tumor cell lines except MCF-7.

\section{Experimental}

\subsection{General experimental procedures}

1D and 2D NMR spectra were recorded on a Bruker Avance III $400 \mathrm{NMR}$ instrument at $400 \mathrm{MHz}$ for ${ }^{1} \mathrm{H}$ NMR and $100 \mathrm{MHz}$ for ${ }^{13} \mathrm{C}$ NMR. Chemical shift values $(\delta)$ are given in parts per million (ppm), and the coupling constants are in Hz. Low-resolution and high-resolution MS were recorded on Shimadzu LCMS-DQ8000 $\alpha$ and JEOL HX110A spectrometers, respectively. Optical rotations were measured at 25 ${ }^{\circ} \mathrm{C}$ with a JASCO Dip-370 digital polarimeter using $\mathrm{MeOH}$ or acetone as solvent. UV spectra were recorded in $\mathrm{MeOH}$ using a Shimadzu UV-1601 UV-Vis spectrometer. Column chromatography (CC) was performed using Baker silica gel $40 \mu \mathrm{m}$ flash chromatography packing (J. T. Baker) or Sephadex LH-20 (25-100 $\mu \mathrm{m} ; \mathrm{GE}$ Healthcare). Analytical and preparative thin-layer chromatography (TLC) were performed on pre-coated $0.20 \mathrm{~mm}$ thick plates of silica gel 60 F254 (Merck). HPLC purifications were carried out on a $10 \times 250 \mathrm{~mm}$ Phenomenex Luna $5 \mu \mathrm{m} \mathrm{C18}$ column with a Waters Delta Prep system consisting of a PDA 996 detector. MM2 energy minimizations of possible conformations of compounds were performed using CambridgeSoft Chembio3D Ultra.

\subsection{Fungal material}

Endophyte NC1214 was isolated on 2\% malt extract agar from surface-sterilized, photosynthetic tissue of a freshly collected sample of Hypnum sp. (Hypnaceae; Hypnum moss) obtained from a granite 
bald in mixed deciduous forest in the southern Appalachian Mountains near Highlands, North Carolina (for isolation details, see U'Ren et al., 2012a). The strain was accessioned as a living mycelial voucher at the Robert L. Gilbertson Mycological Herbarium (MYCO-ARIZ, NC1214). Total genomic DNA was isolated from fresh mycelium and the nuclear ribosomal internal transcribed spacers and $5.8 \mathrm{~s}$ gene (ITS rDNA; ca. 600 base pairs [bp]) and the adjacent portion of the nuclear ribosomal large subunit (LSU rDNA) was amplified as single fragment by PCR (U'Ren et al., 2012b). The product (1147 bp) was visualized on a $1 \%$ agarose gel, cleaned, normalized, and sequenced as described previously (U'Ren et al., 2012b). Sequencing reads were assembled, bases were called, and quality scores were assigned by phred (Ewing and Green, 1998) and phrap (Ewing et al., 1998) through Mesquite (Maddison and Maddison, 2011), followed by manual editing in Sequencher (Gene Codes Corp.). The resulting bidirectional sequence has been deposited in GenBank (accession JQ761854.1). Phylogenetic analyses of >2400 endophytic fungi and related strains from lichens for a related study (Chen et al., 2015), coupled with rich taxon sampling from GenBank and focusing only on the conserved 5.8S and LSUrDNA sequences, placed the isolate within Xylariaceae (Xylariales, Sordariomycetes, Pezizomycotina, Ascomycota). Multilocus analyses with sampling across the Xylariaceae (U'Ren et al., 2012) indicated that NC1214 was part of a clade consisting of endophytes and endolichenic fungi that is sister to the clade containing Xylaria coccophora. Pending description of this novel clade, we refer to this strain conservatively as Xylaria sp. NC1214.

\subsection{Fermentation, extraction and isolation}

A seed culture of Xylaria sp. NC1214 grown on PDA for 2 weeks was used for inoculation. Mycelia were scraped out and vortexed with sterile PDB $(90 \mathrm{~mL})$ and filtered through a $100 \mu \mathrm{m}$ sterile filter to separate spores and/or fragments of hyphae from the mycelia. Absorbance of the filtrate was measured (at $600 \mathrm{~nm}$ ) and adjusted to 0.6. This filtrate was used to inoculate $10 \times 2.0$ L Erlenmeyer flasks, each holding $1.0 \mathrm{~L}$ of the medium (PDB) containing $0.25 \mathrm{mM}$ aq. $\mathrm{CuSO}_{4}$ and incubated at $160 \mathrm{rpm}$ and $28{ }^{\circ} \mathrm{C}$. After 14 days, mycelia were separated by filtration, and the filtrate was extracted with EtOAc $(3 \times 5 \mathrm{~L})$. 
Evaporation of the EtOAc extract under reduced pressure afforded the crude extract ( $3.24 \mathrm{~g})$. A portion (3.04 g) of this extract was partitioned between $\mathrm{MeOH}: \mathrm{H}_{2} \mathrm{O}$ (80:20) and hexanes and the resulting MeOH: $\mathrm{H}_{2} \mathrm{O}(80: 20)$ fraction was diluted with $\mathrm{H}_{2} \mathrm{O}$ to $\mathrm{MeOH}: \mathrm{H}_{2} \mathrm{O}(50: 50)$ and extracted (x 3) with $\mathrm{CHCl}_{3}$. The $\mathrm{CHCl}_{3}$ extracts were combined and evaporated under reduced pressure to obtain the $\mathrm{CHCl}_{3}$ fraction (2.78 g). The $\mathrm{MeOH}: \mathrm{H}_{2} \mathrm{O}$ (80:20) fraction after extraction with $\mathrm{CHCl}_{3}$ was evaporated to afford the aq. $\mathrm{MeOH}$ fraction $(0.20 \mathrm{~g})$. A portion of the above $\mathrm{CHCl}_{3}$ fraction $(2.73 \mathrm{~g})$ was subjected to Sephadex $\mathrm{LH}-20$ (100 g) gel-permeation chromatography and eluted sequentially with $350 \mathrm{~mL}$ each of hexanes: $\mathrm{CH}_{2} \mathrm{Cl}_{2}$ (4:1), $\mathrm{CH}_{2} \mathrm{Cl}_{2}$ :acetone (4:1), $\mathrm{CH}_{2} \mathrm{Cl}_{2}$ :acetone (2:3), and $\mathrm{MeOH}$, respectively. Evaporation of these yielded fractions A $(0.60 \mathrm{~g}), \mathrm{B}(1.97 \mathrm{~g}), \mathrm{C}(0.11 \mathrm{~g})$, and D $(0.02 \mathrm{~g})$, respectively. Fraction A $(0.59 \mathrm{~g})$ was subjected to chromatography over a column of RP C-18 and eluted with a gradient of $\mathrm{MeOH}: \mathrm{H}_{2} \mathrm{O}(60: 40$, 70:30, 80:20, 90:10, 100:0; each $120 \mathrm{~mL})$ to afford five fractions A1-A5, respectively. Fraction A1 (135.4 mg) was subjected to silica gel chromatography and eluted with $\mathrm{CHCl}_{3}: \mathrm{MeOH}$ (from 98:2 to 90:10) to give five fractions A1-1 to A1-5. The major fraction A1-3 (50.3 mg) was further fractionated by $\mathrm{C}-18$ (20 g) $\mathrm{CC}$, eluted with a gradient initially of $\mathrm{MeOH}: \mathrm{H}_{2} \mathrm{O}$ (50:50) to $\mathrm{MeOH}$, followed by HPLC purification [C-18; $\left.\mathrm{MeOH}: \mathrm{H}_{2} \mathrm{O}(55: 45)\right]$ to afford $6\left(0.5 \mathrm{mg} ; R_{\mathrm{f}} 0.44, \mathrm{CHCl}_{3}-\mathrm{MeOH}, 14: 1\right)$ and $12(2.4$ $\left.\mathrm{mg} ; R_{\mathrm{f}} 0.69, \mathrm{CHCl}_{3}-\mathrm{MeOH}, 14: 1\right)$. Fraction $\mathrm{A} 2(386.8 \mathrm{mg})$ was further fractionated by silica gel $\mathrm{CC}$ using $\mathrm{CHCl}_{3}-\mathrm{MeOH}$ (from 98:2 to 90:10) as the eluent to give 15 sub-fractions A2-1 to A2-15. Evaporation of fractions A2-8, A2-11, and A2-12 under reduced pressure yielded $7\left(0.6 \mathrm{mg}, R_{\mathrm{f}} 0.26, \mathrm{CHCl}_{3}-\mathrm{MeOH}^{\mathrm{O}}\right.$, 14:1), $1\left(0.8 \mathrm{mg} ; R_{\mathrm{f}} 0.34, \mathrm{CHCl}_{3}-\mathrm{MeOH}, 10: 1\right)$ and 3 (1.8 mg; $\left.R_{\mathrm{f}} 0.30, \mathrm{CHCl}_{3}-\mathrm{MeOH}, 10: 1\right)$, respectively. Further fractionation of $\mathrm{A} 2-1(78.2 \mathrm{mg})$ by silica gel $(12 \mathrm{~g}) \mathrm{CC}$ and elution with $\mathrm{CHCl}_{3}-\mathrm{MeOH}$ (from 99:1 to 95:5) followed by prep-HPLC purification [C-18; $\left.\mathrm{MeOH}: \mathrm{H}_{2} \mathrm{O}(55: 45)\right]$ afforded 14 (25.3 mg, $R_{\mathrm{t}}$ $20.0 \mathrm{~min})$ and $15\left(0.7 \mathrm{mg}, R_{\mathrm{t}} 38.1 \mathrm{~min}\right)$. Purification of fraction A2-7 (21.4 mg) by prep-HPLC [C-18; MeOH: $\left.\mathrm{H}_{2} \mathrm{O}(60: 40)\right]$ afforded $5\left(2.0 \mathrm{mg} ; R_{\mathrm{f}} 0.26, \mathrm{CHCl}_{3}-\mathrm{MeOH}, 14: 1\right)$. Further fractionation of fraction B (1.97 g) by a RP C-18 CC and elution with a gradient of $\mathrm{MeOH}: \mathrm{H}_{2} \mathrm{O}$ (50:50, 60:40, 70:30, 80:20, 90:10, 100:0; each $350 \mathrm{~mL}$ ) afforded six fractions B1-B6, respectively. Fraction B1 (279.4 mg) was further 
separated using silica gel $\mathrm{CC}$ and eluted with $\mathrm{CHCl}_{3}-\mathrm{MeOH}$ (from 98:2 to 85:15) followed by purification RP C-18 CC [MeOH: $\mathrm{H}_{2} \mathrm{O}$ (50:50 to 70:30)] to give 11 (2.4 mg; $R_{\mathrm{f}} 0.32, \mathrm{CH}_{2} \mathrm{Cl}_{2}$-acetone, 2:1). Fraction B2 (762.2 mg) was separated by silica gel $\mathrm{CC}$ and eluted with $\mathrm{CHCl}_{3}-\mathrm{MeOH}$ (from 98:2 to 85:15) to give 13 sub-fractions, B2-1 to B2-13. Fraction B2-5 (45.6 mg) was separated by C-18 (10 g) CC and eluted with $\mathrm{MeOH}: \mathrm{H}_{2} \mathrm{O}$ (50:50 to 70:30) to afford 2 (2.0 mg; $R_{\mathrm{f}} 0.40, \mathrm{CH}_{2} \mathrm{Cl}_{2}$-acetone, 5:2). B2-9 (32.0 mg) was further purified over a column (10 g) of RP C-18 and eluted with $\mathrm{MeOH}: \mathrm{H}_{2} \mathrm{O}$ (50:50 to 70:30) to afford $10\left(2.3 \mathrm{mg} ; R_{\mathrm{f}} 0.30, \mathrm{CH}_{2} \mathrm{Cl}_{2}\right.$-acetone, $\left.2: 1\right)$. Fraction B3 (494.6 mg) was separated by silica gel ( $\left.80 \mathrm{~g}\right) \mathrm{CC}$ and eluted with $\mathrm{CHCl}_{3}-\mathrm{MeOH}$ (from 98:2 to 85:15) to give 18 sub-fractions, $\mathrm{B} 3-1$ to $\mathrm{B} 3-18$. Evaporation of B3-4 under reduced pressure afforded 13 (137.1 mg; $\left.R_{\mathrm{f}} 0.47, \mathrm{CHCl}_{3}-\mathrm{MeOH}, 5: 1\right)$. Fraction B3-13 (23.5 mg) was further separated by RP C-18 CC and eluted with $\mathrm{MeOH}: \mathrm{H}_{2} \mathrm{O}$ (70:30 to 80:20) to give 4 (1.6 mg; $R_{\mathrm{f}} 0.23, \mathrm{CH}_{2} \mathrm{Cl}_{2}$-acetone, $1: 1$ ). In order to isolate the polar metabolites of this fungal strain, the $\mathrm{MeOH}: \mathrm{H}_{2} \mathrm{O}$ (50:50) fraction and the fractions $\mathrm{C}-\mathrm{D}$ obtained from the $\mathrm{CHCl}_{3}$ fraction resulting from solvent-solvent partitioning of the original EtOAc extract which had similar TLC profiles were combined (0.33 g) and separated by C18 RP prep-HPLC with solvent gradients of $10 \%$ to $58 \%$ aqueous $\mathrm{MeCN}$ (0-30 min), 58\% aqueous $\mathrm{MeCN}$ to $\mathrm{MeCN}$ (30-35 min), and 100\% $\mathrm{MeCN}$ (35-40 min), yielding 8 $\left(148.0 \mathrm{mg} ; R_{\mathrm{t}} 17.8 \mathrm{~min}\right)$ and $9\left(43.2 \mathrm{mg} ; R_{\mathrm{t}} 23.6 \mathrm{~min}\right)$.

\subsection{Spectroscopic data of metabolites}

\subsubsection{Xylaguaianol A (1)}

Colorless oil; $[\alpha]^{25}+30.2(c 0.08, \mathrm{MeOH})$; for ${ }^{13} \mathrm{C}$ NMR and ${ }^{1} \mathrm{H}$ NMR spectroscopic data, see Tables 1 and 2; APCIMS m/z $277\left[\mathrm{M}-\mathrm{H}_{2} \mathrm{O}+\mathrm{Na}\right]^{+}(25), 237\left[\mathrm{M}-2 \mathrm{H}_{2} \mathrm{O}+\mathrm{H}\right]^{+}(20), 219\left[\mathrm{M}-3 \mathrm{H}_{2} \mathrm{O}+\mathrm{H}\right]^{+}$ (100); positive HRESIMS $m / z 255.1956\left[\mathrm{M}-\mathrm{H}_{2} \mathrm{O}+\mathrm{H}\right]^{+}$(calcd for $\mathrm{C}_{15} \mathrm{H}_{27} \mathrm{O}_{3}, 255.1960$ ).

\subsubsection{Xylaguaianol B (2)}

Colorless oil; $[\alpha]^{25}+1.2(c 0.12, \mathrm{MeOH})$; for ${ }^{13} \mathrm{C}$ NMR and ${ }^{1} \mathrm{H}$ NMR spectroscopic data, see Tables 1 and 2; positive APCIMS m/z $277\left[\mathrm{M}-\mathrm{H}_{2} \mathrm{O}+\mathrm{Na}\right]^{+}(20), 237\left[\mathrm{M}-2 \mathrm{H}_{2} \mathrm{O}+\mathrm{H}\right]^{+}(34), 219\left[\mathrm{M}-3 \mathrm{H}_{2} \mathrm{O}+\mathrm{H}\right]^{+}$ 
(100), $201\left[\mathrm{M}-4 \mathrm{H}_{2} \mathrm{O}+\mathrm{H}\right]^{+}$(55); positive HRESIMS $\mathrm{m} / z 255.1954\left[\mathrm{M}-\mathrm{H}_{2} \mathrm{O}+\mathrm{H}\right]^{+}$(calcd for $\mathrm{C}_{15} \mathrm{H}_{27} \mathrm{O}_{3}$, 255.1960).

\subsubsection{Xylaguaianol C (3)}

Colorless oil; $[\alpha]^{25}+22.2(c 0.16, \mathrm{MeOH})$; for ${ }^{13} \mathrm{C}$ NMR and ${ }^{1} \mathrm{H}$ NMR spectroscopic data, see Tables 1 and 2; positive APCIMS m/z $257[\mathrm{M}+\mathrm{H}]^{+}(10), 221\left[\mathrm{M}-2 \mathrm{H}_{2} \mathrm{O}+\mathrm{H}\right]^{+}(85), 207\left[\mathrm{M}-\mathrm{H}_{2} \mathrm{O}-\mathrm{CH}_{2} \mathrm{OH}\right]^{+}$ (100), $203\left[\mathrm{M}-3 \mathrm{H}_{2} \mathrm{O}+\mathrm{H}\right]^{+}$(68); positive HRESIMS m/z $279.1924[\mathrm{M}+\mathrm{Na}]^{+}$(calcd for $\mathrm{C}_{15} \mathrm{H}_{28} \mathrm{O}_{3} \mathrm{Na}$, 279.1931).

\subsubsection{Xylaguaianol D (4)}

Colorless oil; $[\alpha]_{\mathrm{D}}^{25}+14.7(c$ 0.09, $\mathrm{MeOH})$; UV $(\mathrm{MeOH}) \lambda_{\max }(\log \varepsilon) 212(3.7) \mathrm{nm}$; for ${ }^{13} \mathrm{C}$ NMR and ${ }^{1} \mathrm{H}$ NMR spectroscopic data, see Tables 1 and 2; positive APCIMS $m / z 233\left[\mathrm{M}-\mathrm{C}_{2} \mathrm{H}_{4}+\mathrm{Na}\right]^{+}(100)$; positive HRESIMS $m / z$ 261.1876 $[\mathrm{M}+\mathrm{Na}]^{+}$(calcd for $\mathrm{C}_{15} \mathrm{H}_{26} \mathrm{O}_{2} \mathrm{Na}, 261.1831$ ).

\subsubsection{Isocadinanol A (5)}

Colorless oil; $[\alpha]^{25}+10.1\left(c\right.$ 0.10, MeOH); ${ }^{1} \mathrm{H}$ NMR (400 MHz, $\left.\mathrm{CDCl}_{3}\right) \delta 3.43(1 \mathrm{H}, \mathrm{m}, \mathrm{H}-9), 2.92$ (1H, dd, $J=16.0,1.6 \mathrm{~Hz}, \mathrm{H}-4), 2.12$ (1H, ddd, $J=13.2,4.4,2.4 \mathrm{~Hz}, \mathrm{H}-8 \alpha), 1.74(1 \mathrm{H}, \mathrm{m}, \mathrm{H}-11), 1.67$ (1H,

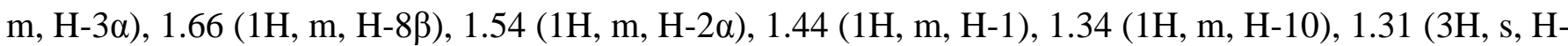

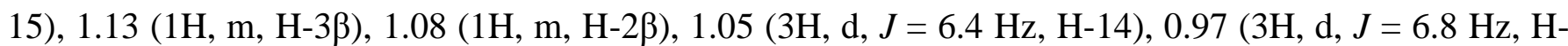
13), $0.91(1 \mathrm{H}, \mathrm{m}, \mathrm{H}-7), 0.86(3 \mathrm{H}, \mathrm{d}, J=6.4 \mathrm{~Hz}, \mathrm{H}-12) ;{ }^{13} \mathrm{C} \mathrm{NMR}\left(100 \mathrm{MHz}, \mathrm{CDCl}_{3}\right) \delta 71.3(\mathrm{CH}, \mathrm{C}-9)$, $68.3(\mathrm{CH}, \mathrm{C}-4), 66.4$ (C, C-6), $65.9(\mathrm{C}, \mathrm{C}-5), 49.5(\mathrm{CH}, \mathrm{C}-7), 43.9(\mathrm{CH}, \mathrm{C}-10), 37.7$ (CH, C-1), $37.2\left(\mathrm{CH}_{2}\right.$, C-3), $34.8\left(\mathrm{CH}_{2}, \mathrm{C}-8\right), 27.8\left(\mathrm{CH}_{3}, \mathrm{C}-15\right), 27.5(\mathrm{CH}, \mathrm{C}-11), 21.2\left(\mathrm{CH}_{3}, \mathrm{C}-13\right), 21.0\left(\mathrm{CH}_{3}, \mathrm{C}-12\right), 19.7\left(\mathrm{CH}_{2}\right.$, C-2), $14.9\left(\mathrm{CH}_{3}, \mathrm{C}-14\right)$; positive APCIMS m/z $201\left[\mathrm{M}-3 \mathrm{H}_{2} \mathrm{O}+\mathrm{H}\right]^{+}(38), 219\left[\mathrm{M}-2 \mathrm{H}_{2} \mathrm{O}+\mathrm{H}\right]^{+}(100), 237$ $\left[\mathrm{M}-\mathrm{H}_{2} \mathrm{O}+\mathrm{H}\right]^{+}(70)$; HRESIMS m/z $277.1773[\mathrm{M}+\mathrm{Na}]^{+}$(calcd for $\mathrm{C}_{15} \mathrm{H}_{28} \mathrm{O}_{3} \mathrm{Na}, 277.1774$ ).

\subsubsection{9-Hydroxyxylarone (6)}

White amorphous solid; $[\alpha]_{\mathrm{D}}^{25}+8.5\left(c\right.$ 0.06, MeOH); UV (MeOH) $\lambda_{\max }(\log \varepsilon) 309.5(1.8), 225.5$ (3.9) nm; ${ }^{1} \mathrm{H}$ NMR (400 MHz, $\left.\mathrm{CDCl}_{3}\right) \delta 6.49(1 \mathrm{H}, \mathrm{dd}, J=8.8,1.2 \mathrm{~Hz}, \mathrm{H}-8), 6.18(1 \mathrm{H}, \mathrm{s}, \mathrm{H}-5), 4.43(1 \mathrm{H}$, dt, $J=8.6,6.6 \mathrm{~Hz}, \mathrm{H}-9), 3.90\left(3 \mathrm{H}, \mathrm{s}, \mathrm{OCH}_{3}-4\right), 1.94(1 \mathrm{H}, \mathrm{s}, \mathrm{H}-13), 1.93(3 \mathrm{H}, \mathrm{s}, \mathrm{H}-12), 1.55-1.75(2 \mathrm{H}, \mathrm{m}$, 
$\mathrm{H}-10), 0.92(3 \mathrm{H}, \mathrm{t}, J=7.2 \mathrm{~Hz}, \mathrm{H}-11) ;{ }^{13} \mathrm{C}$ NMR $\left(100 \mathrm{MHz}, \mathrm{CDCl}_{3}\right) \delta 164.1$ (C, C-4), $163.8(\mathrm{C}, \mathrm{C}-2)$,

159.1 (C, C-6), 135.8 (CH, C-8), 127.7 (C, C-7), 102.8 (C, C-3), 92.9 (CH, C-5), 70.0 (CH, C-9), 56.2 $\left(\mathrm{CH}_{3}, \mathrm{OCH}_{3}-4\right), 30.4\left(\mathrm{CH}_{2}, \mathrm{C}-10\right), 13.0\left(\mathrm{CH}_{3}, \mathrm{C}-13\right), 9.6\left(\mathrm{CH}_{3}, \mathrm{C}-11\right), 8.7\left(\mathrm{CH}_{3}, \mathrm{C}-12\right)$; positive APCIMS $m / z 239[\mathrm{M}+\mathrm{H}]^{+}(100)$; positive HRESIMS $m / z 239.1271[\mathrm{M}+\mathrm{H}]^{+}$(calcd for $\mathrm{C}_{13} \mathrm{H}_{19} \mathrm{O}_{4}, 239.1278$ ).

\subsection{Cytotoxicity Assay}

The resazurin-based colorimetric (AlamarBlue) assay was employed for evaluation of cytotoxicity in vitro of samples against human prostate adenocarcinoma (PC-3M), human non-small cell lung (NCIH460), human CNS glioma (SF-268), human breast (MCF-7), and human metastatic breast adenocarcinoma (MDA-MB-231) as described previously (Wijeratne et al., 2012; Wijeratne et al., 2014). Doxorubicin and DMSO were used as positive and negative controls, respectively.

\section{Acknowledgements}

The authors thank NCI (R01 CA90265), NIGMS (P41 GM09060), NSF (DEB-0640996 to AEA), and the China Scholarship Council (Fellowship to H. Wei) for financial support for this work, and Drs. F. Lutzoni and J. Miadlikowska (Duke University) for their help with the collection of the fungal strain.

\section{References}

Calhoun, L.A., Findlay, J.A., Miller, J.D., Whitney, N.J., 1992. Metabolites toxic to spruce budworm from balsam fir needle endophytes. Mycol. Res. 96, 282-286.

Chen, K.-H., Miadlikowska, J., Molnár, K., Arnold, A.E., U'Ren, J.M., Gaya, E., Gueidan, C., Lutzoni, F., 2015. Phylogenetic analyses of eurotiomycetous endophytes reveal their affinities to Chaetothyriales, Eurotiales, and a new order-Phaeomoniellales. Mol. Phylogen. Evol. 85,117-30. 
Davis, R.A., Pierens, G.K., 2006. ${ }^{1} \mathrm{H}$ and ${ }^{13} \mathrm{C}$ NMR assignments for two new xanthones from the endophytic fungus Xylaria sp. FRR 5657. Magn. Reson. Chem. 44, 966-968.

Edwards, R.L., Maitland, D.J., Whalley, A.J.S., 1989. Metabolites of the higher fungi. Part 24. Cytochalasin N, O, P, Q, and R. New cytochalasins from the fungus Hypoxylon terricola Mill. J. Chem. Soc., Perkin Trans. 1, 57-65.

Espada, A., Rivera-Sagredo, A., De La Fuente, J.M., Hueso-Rodriguez, J.A., Elson, S.W., 1997. New cytochalasins from the fungus Xylaria hypoxylon. Tetrahedron 53, 6485-6492.

Ewing, B., Green, P., 1998. Base-calling of automated sequencer traces using phred. II. Error probabilities. Genome Res. 8, 186-194.

Ewing, B., Hillier, L., Wendl, M.C., Green, P., 1998. Base-calling of automated sequencer traces using phred. I. Accuracy assessment. Genome Res. 8, 175-185.

Gunatilaka, A.A.L., 2006. Natural products from plant-associated microorganisms: distribution, structural diversity, bioactivity, and implications of their occurrence. J. Nat. Prod. 69, 509-526.

Healy, P.C., Hocking, A., Tran-Dinh, N., Pitt, J.I., Shivas, R.G., Mitchell, J.K., Kotiw, M., Davis, R.A., 2004. Xanthones from a microfungus of the genus Xylaria. Phytochemistry 65, 2373-2378.

Itoh, Y., Takahashi, S., Arai, M., 1982. Structure of gliocladic acid. J. Antibiot. 35, 541-542.

Jimenez-Romero, C., Ortega-Barria, E., Arnold, A.E., Cubilla-Rios, L., 2008. Activity against

Plasmodium falciparum of lactones isolated from the endophytic fungus Xylaria sp. Pharm. Biol.

46, 700-703.

Klaiklay, S., Rukachaisirikul, V., Sukpondma, Y., Phongpaichit, S., Buatong, J., Bussaban, B., 2012. Metabolites from the mangrove-derived fungus Xylaria cubensis PSU-MA34. Arch. Pharm. Res. 35, $1127-1131$.

Li, Y., Hu, Z., Lu, C., Shen, Y., 2010. Four new terpenoids from Xylaria sp. 101. Helv. Chim. Acta 93, 796-802.

Lin, Y., Wu, X., Feng, S., Jiang, G., Zhou, S., Vrijmoed, L.L.P., Jones, E.B.G., 2001. A novel $N$ - 
cinnamoylcyclopeptide containing an allenic ether from the fungus Xylaria sp. (strain\# 2508) from the South China Sea. Tetrahedron Lett. 42, 449-451.

Maddison, W.P., Maddison, D.R., 2011. Mesquite, www.mesquiteproject.org.

Paranagama P.A., Wijeratne E.M.K., Gunatilaka A.A.L., 2007. Uncovering biosynthetic potential of plant-associated fungi: Effect of culture conditions on metabolite production by

Parasphaerosphaeria quadriseptata and Chaetomium chiversii, J. Nat. Prod. 70, 1939-1945.

Schulz, B., Boyle, C., Draeger, S., Römmert, A.K., Krohn, K., 2002. Endophytic fungi: a source of novel biologically active secondary metabolites. Mycol. Res. 106, 996-1004.

Schüffler, A., Sterner. O., Anke, H., 2007. Cytotoxic $\alpha$-pyrones from Xylaria hypoxylon. Z. Naturforsch. $62 \mathrm{c}, 169-172$.

Song, F., Wu, S., Zhai, Y., Xuan, Q., Wang, T., 2014. Secondary metabolites from the genus Xylaria and their bioactivities. Chem. Biodivers. 11, 673-694.

Sung, T.V., Steffan, B., Steglich, B., Klebe, G., Adam, G., 1992. Sesquiterpenoids from the roots of Homalomena aromatica. Phytochemistry 31, 3515-3520.

U'Ren, J.M., Lutzoni, F., Miadlikowska, J., Laetsch, A.D., Arnold, A.E., 2012a. Host and geographic structure of endophytic and endolichenic fungi at a continental scale. Amer. J. Botany 99, 898-914.

U'Ren, J.M., Arnold, A.E., 2012b. Multigene phylogenetic analysis of the Xylariaceae: what are the roles of previously unknown endophytic and endolichenic fungi? Inoculum 63, 50.

Van Goietsenoven, G., Mathieu, V., Andolfi, A., Cimmino, A., Lefranc, F., Kiss R., Evidente, A., 2011. In vitro growth inhibitory effects of cytochalasins and derivatives in cancer cells. Planta Med. 77, 711717.

Whitesell, J.K., Minton, M.A., 1987. Stereochemical analysis of alicyclic compounds by C-13 NMR spectroscopy. Chapman and Hall Ltd, New York.

Wijeratne, E.M.K., Bashyal, B.P., Liu, M.X., Rocha, D.D., Gunaherath, G.M.K.B., U'Ren, J.M., Gunatilaka, M.K., Arnold, A.E., Whitesell, L., Gunatilaka, A.A.L., 2012. Geopyxins A-E, ent- 
kaurane diterpenoids from endolichenic fungal strains Geopyxis aff. majalis and Geopyxis sp. AZ0066: structure-activity relationships of geopyxins and their analogues. J. Nat. Prod. 75, 361-369.

Wijeratne, E.M.K., Xu, Y., Schrez-Shouval, R., Marron, M.T., Rocha, D.D., Liu, M.X., Costa-Lotufo, L.V., Santagata, S., Lindquist, S., Whitesell, L., Gunatilaka, A.A.L., 2014. Structure-activity relationships for withanolides as inducers of the cellular heat-shock response, J. Med. Chem. 57, 2851-2863.

Wu, S., He, J., Li, X., Huang, R., Song, F., Chen, Y., Miao, C., 2014. Guaiane sesquiterpenes and isopimarane diterpenes from an endophytic fungus Xylaria sp. Phytochemistry 105, 197-204.

Wu, W., Dai, H., Bao, L., Ren, B., Lu, J., Luo, Y., Guo, L., Zhang, L., Liu, H., 2011. Isolation and structural elucidation of proline-containing cyclopentapeptides from an endolichenic Xylaria sp. J. Nat. Prod. 74, 1303-1308.

$\mathrm{Xu}$, Y., Zhang, H., Wan, X., Zou, Z., 2009. Complete assignments of ${ }^{1} \mathrm{H}$ and ${ }^{13} \mathrm{C}$ NMR data for two new sesquiterpenes from Cyperus rotundus L. Magn. Reson. Chem. 47, 527-531.

Xu, Y., Bashyal, B.P., Liu, M.X., Espinosa-Artiles, P., U'Ren, J.M., Arnold, A.E., Gunatilaka, A.A.L., 2015. Cytotoxic cytochalasins and other metabolites from Xylariaceae sp. FL0390, a fungal endophyte of Spanish moss, Nat. Prod. Commun. In press.

Yan, S., Li, S., Wu, W., Zhao, F., Bao, L., Ding, R., Gao, H., Wen, H., Song, F., Liu, H., 2011. Terpenoid and phenolic metabolites from the fungus Xylaria sp. associated with termite nests. Chem. Biodivers. 8, 1689-1700.

Zhang, H., Song, Y., Tan, R., 2006. Biology and chemistry of endophytes. Nat. Prod. Rep. 23, 753-771.

Zeng, Y., Gu, H., Zuo, W., Zhang, L., Bai, H., Guo, Z., Proksch, P., Mei, W., Dai, H, 2015. Two new sesquiterpenoids from endophytic fungus J3 isolated from Mangrove Plant Ceriops tagal. Arch. Pharm. Res. 38, 673-676. 
FIGURES
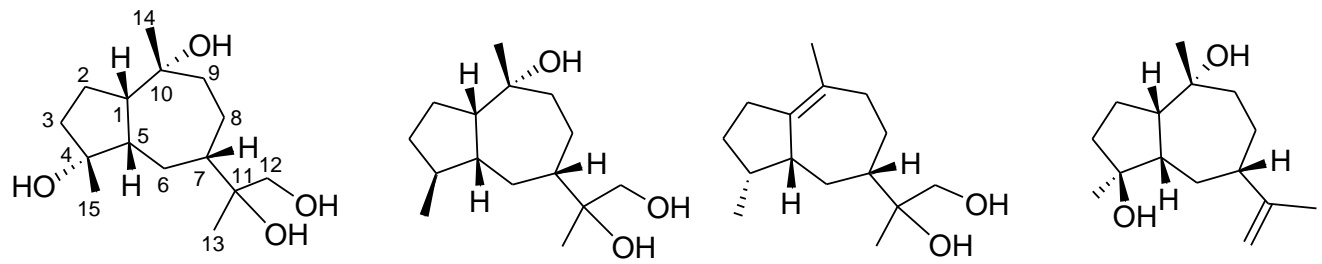

Xylaguaianol A $\left(\mathbf{1} ; 11 R^{*}\right)$

Xylaguaianol $B\left(2 ; 11 S^{*}\right)$

Xylaguaianol C (3)

Xylaguaianol D (4)

Epi-guaidiol A (7)

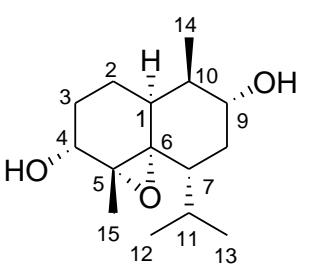<smiles>CCC(O)C=C(C)c1cc(OC)c(C)c(=O)o1</smiles><smiles>CC(C)[C@H]1CCC(CO)=C[C@H]1/C=C(\CO)C(=O)O</smiles>

Isocadinanol A (5)

9-Hydroxylarone (6)

Hydroheptelidic Acid (8)

Gliocladic Acid (9)<smiles>CC(C)[C@]1(O)CC[C@]2(C)C(O)CC[C@](C)(O)C2C1</smiles><smiles>CC(C)(O)C[C@@H]1CC[C@]2(C)C(O)CC[C@H](O)[C@@H]12</smiles>

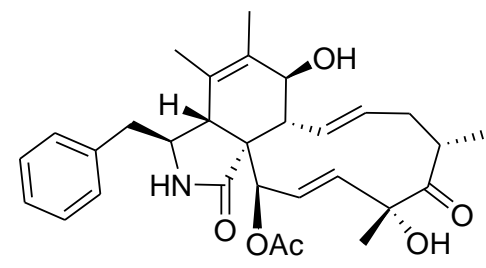

Bullatantriol (10)

$1 \beta, 4 \beta, 7 \alpha$-Trihydroxyeudesmane (11)

Cytochalasin C (12)

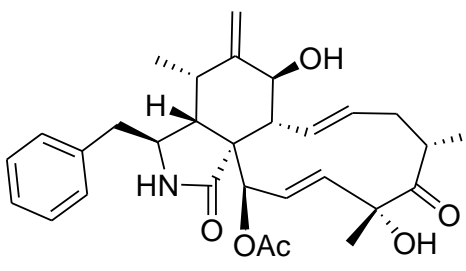

Cytochalasin D (13)

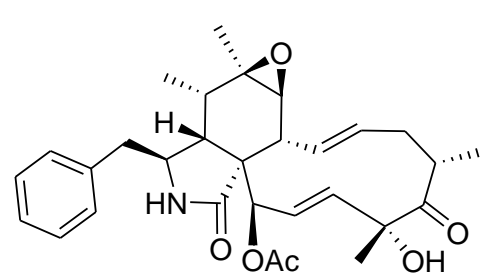

Cytochalasin Q (14)

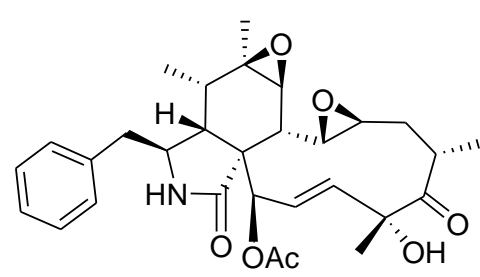

Cytochalasin R (15)

Fig. 1. Structures of metabolites 1-15. 


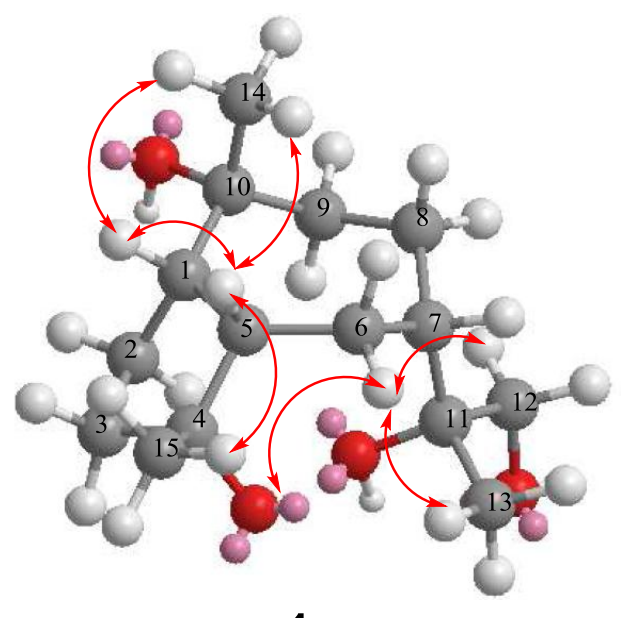

1
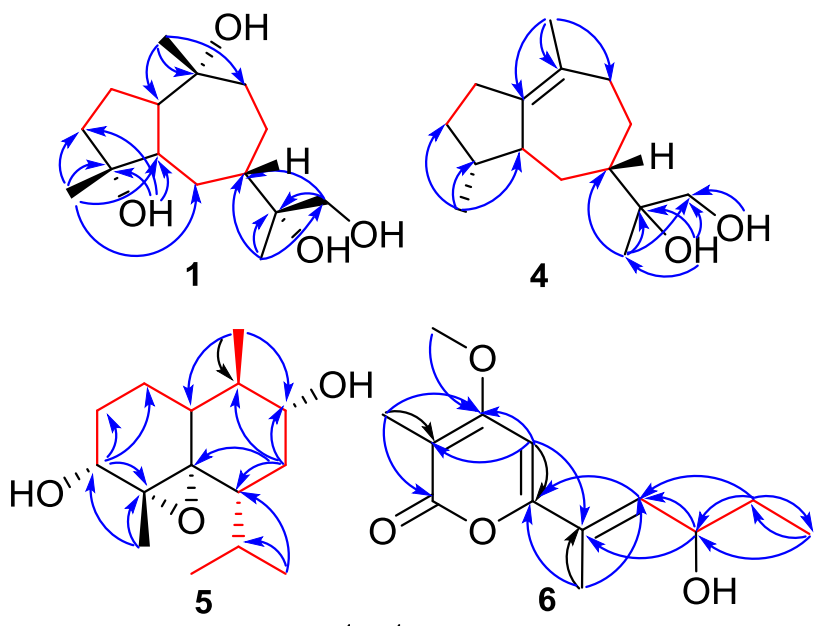

${ }^{1} \mathrm{H}-{ }^{1} \mathrm{H}$ COSY

$\mathrm{HMBC}$

Fig. 2. Key HMBC and ${ }^{1} \mathrm{H}-{ }^{1} \mathrm{H}$ COSY correlations for compounds $\mathbf{1}, \mathbf{4}, \mathbf{5}$, and $\mathbf{6}$.

Fig. 3. Key NOE correlations for compounds $\mathbf{1}$ and $\mathbf{5}$.

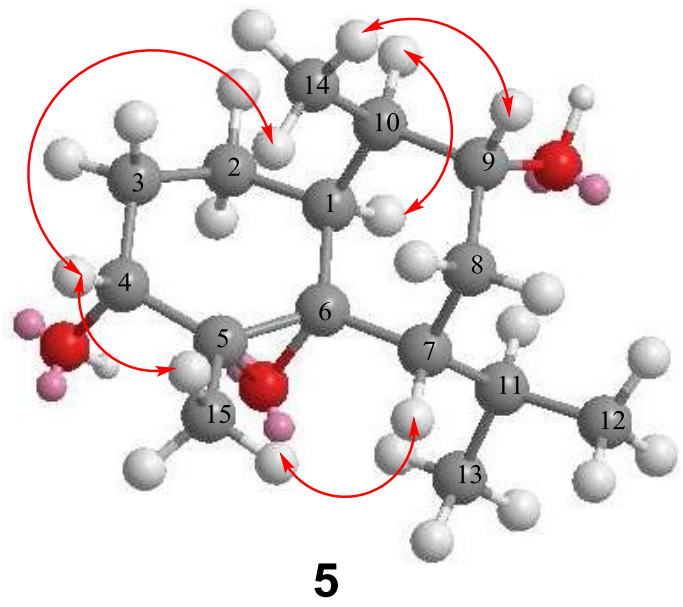

\section{5}


Table 1.

${ }^{1} \mathrm{H}$ NMR (400 MHz) spectroscopic data for compounds $\mathbf{1 - 4}$ (acetone- $d_{6}, \delta$ in ppm, $J$ in $\mathrm{Hz}$ ).

\begin{tabular}{lllll}
\hline position & $\mathbf{1}$ & $\mathbf{2}$ & $\mathbf{3}$ & $\mathbf{4}$ \\
\hline 1 & $2.86 \mathrm{~m}$ & $2.90 \mathrm{~m}$ & $2.05 \mathrm{~m}$ & - \\
$2 \alpha$ & $1.50 \mathrm{~m}$ & $1.53 \mathrm{~m}$ & $1.50 \mathrm{~m}$ & $2.31 \mathrm{~m}$ \\
$2 \beta$ & $1.71 \mathrm{~m}$ & $1.70 \mathrm{~m}$ & $1.64 \mathrm{~m}$ & $2.16 \mathrm{~m}$ \\
$3 \alpha$ & $1.63 \mathrm{~m}$ & $1.67 \mathrm{~m}$ & $1.66 \mathrm{~m}$ & $1.35 \mathrm{~m}$ \\
$3 \beta$ & $1.91 \mathrm{~m}$ & $1.93 \mathrm{~m}$ & $1.21 \mathrm{~m}$ & $1.64 \mathrm{~m}$ \\
4 & - & - & $1.97 \mathrm{~m}$ & $2.08 \mathrm{~m}$ \\
5 & $2.17 \mathrm{~m}$ & $2.24 \mathrm{~m}$ & $1.88 \mathrm{~m}$ & $2.38 \mathrm{~m}$ \\
$6 \alpha$ & $2.17 \mathrm{~m}$ & $2.13 \mathrm{~m}$ & $1.77 \mathrm{~m}$ & $0.81 \mathrm{~m}$ \\
$6 \beta$ & $1.12 \mathrm{~m}$ & $1.20 \mathrm{~m}$ & $0.90 \mathrm{~m}$ & $1.76 \mathrm{~m}$ \\
7 & $1.95 \mathrm{~m}$ & $1.99 \mathrm{~m}$ & $1.89 \mathrm{~m}$ & $1.67 \mathrm{~m}$ \\
$8 \alpha$ & $2.12 \mathrm{~m}$ & $2.08 \mathrm{~m}$ & $1.82 \mathrm{~m}$ & $1.13 \mathrm{~m}$ \\
$8 \beta$ & $1.45 \mathrm{~m}$ & $1.44 \mathrm{~m}$ & $1.14 \mathrm{~m}$ & $2.05 \mathrm{~m}$ \\
$9 \alpha$ & $1.85 \mathrm{~m}$ & $1.70 \mathrm{~m}$ & $1.88 \mathrm{~m}$ & $2.08 \mathrm{~m}$ \\
$9 \beta$ & $1.72 \mathrm{~m}$ & $1.53 \mathrm{~m}$ & $1.37 \mathrm{~m}$ & $2.08 \mathrm{~m}$ \\
$12 \mathrm{a}$ & $3.28-3.33 \mathrm{~m}$ & $3.17-3.22 \mathrm{~m}$ & $3.29-3.36 \mathrm{~m}$ & $3.35-3.40 \mathrm{~m}$ \\
$12 \mathrm{~b}$ & $3.59-3.65 \mathrm{~m}$ & $3.41-3.50 \mathrm{~m}$ & $3.40-3.50 \mathrm{~m}$ & $3.47-3.52 \mathrm{~m}$ \\
13 & $1.25 \mathrm{~s}$ & $1.23 \mathrm{~s}$ & $0.98 \mathrm{~s}$ & $1.00 \mathrm{~s}$ \\
14 & $1.08 \mathrm{~s}$ & $1.07 \mathrm{~s}$ & $1.10 \mathrm{~s}$ & $1.63 \mathrm{~d}(1.2)$ \\
15 & $1.18 \mathrm{~s}$ & $1.20 \mathrm{~s}$ & $0.93 \mathrm{~d}(6.8)$ & $0.88 \mathrm{~d}(7.2)$ \\
$12-\mathrm{OH}$ & $3.50-3.56 \mathrm{~m}$ & & & $3.54-3.60 \mathrm{~m}$ \\
$13-\mathrm{OH}$ & & & $3.03 \mathrm{~s}$ & \\
$14-\mathrm{OH}$ & & & & \\
$15-\mathrm{OH}$ & $3.18 \mathrm{~s}$ & $3.19 \mathrm{~s}$ & & \\
\hline
\end{tabular}


Table 2.

${ }^{13} \mathrm{C}$ NMR (100 MHz) spectroscopic data for compounds $\mathbf{1}-\mathbf{4}$ (acetone- $d_{6}, \delta$ in ppm).

\begin{tabular}{lllll}
\hline position & $\mathbf{1}$ & $\mathbf{2}$ & $\mathbf{3}$ & $\mathbf{4}$ \\
\hline 1 & $55.0, \mathrm{CH}$ & $54.9, \mathrm{CH}$ & $56.6, \mathrm{CH}$ & $142.0, \mathrm{C}$ \\
2 & $26.2, \mathrm{CH}_{2}$ & $26.3, \mathrm{CH}_{2}$ & $26.8, \mathrm{CH}_{2}$ & $30.9, \mathrm{CH}_{2}$ \\
3 & $38.9, \mathrm{CH}_{2}$ & $39.0, \mathrm{CH}_{2}$ & $31.7, \mathrm{CH}_{2}$ & $33.7, \mathrm{CH}_{2}$ \\
4 & $81.9, \mathrm{C}$ & $81.8, \mathrm{C}$ & $40.0, \mathrm{CH}$ & $39.9, \mathrm{CH}$ \\
5 & $49.3, \mathrm{CH}$ & $49.3, \mathrm{CH}$ & $47.9, \mathrm{CH}$ & $47.3, \mathrm{CH}$ \\
6 & $36.0, \mathrm{CH}_{2}$ & $36.3, \mathrm{CH}_{2}$ & $22.3, \mathrm{CH}$ & $29.6, \mathrm{CH}_{2}$ \\
7 & $33.4, \mathrm{CH}$ & $32.2, \mathrm{CH}$ & $44.9, \mathrm{CH}$ & $50.3, \mathrm{CH}$ \\
8 & $25.9, \mathrm{CH}_{2}$ & $25.8, \mathrm{CH}_{2}$ & $25.0, \mathrm{CH}_{2}$ & $27.6, \mathrm{CH}_{2}$ \\
9 & $29.7^{\mathrm{a}}, \mathrm{CH}_{2}$ & $28.9^{\mathrm{a}}, \mathrm{CH}_{2}$ & $34.3, \mathrm{CH}_{2}$ & $35.8, \mathrm{CH}_{2}$ \\
10 & $75.3, \mathrm{C}$ & $75.2, \mathrm{C}$ & $74.0, \mathrm{C}$ & $129.7, \mathrm{C}$ \\
11 & $77.6, \mathrm{C}$ & $77.6, \mathrm{C}$ & $75.9, \mathrm{C}$ & $75.2, \mathrm{C}$ \\
12 & $68.8, \mathrm{CH}_{2}$ & $70.2, \mathrm{CH}_{2}$ & $69.2, \mathrm{CH}_{2}$ & $69.0, \mathrm{CH}_{2}$ \\
13 & $26.6, \mathrm{CH}_{3}$ & $23.8, \mathrm{CH}_{3}$ & $19.3, \mathrm{CH}_{3}$ & $21.0, \mathrm{CH}_{3}$ \\
14 & $33.3, \mathrm{CH}_{3}$ & $33.2, \mathrm{CH}_{3}$ & $31.9, \mathrm{CH}_{3}$ & $22.5, \mathrm{CH}_{3}$ \\
15 & $24.5, \mathrm{CH}_{3}$ & $24.6, \mathrm{CH}_{3}$ & $16.8, \mathrm{CH}_{3}$ & $15.6, \mathrm{CH}_{3}$ \\
\hline
\end{tabular}

${ }^{\mathrm{a} O v e r l a p p i n g ~ w i t h ~ s i g n a l s ~ d u e ~ t o ~ t h e ~ s o l v e n t . ~}$ 
Table 3.

Cytotoxicity data for cytochalasins C (12), D (13) and Q (14). ${ }^{\mathrm{a}}$

\begin{tabular}{llllll}
\hline \multirow{2}{*}{ Compound } & \multicolumn{5}{c}{ Tumor Cell Line $^{\mathrm{b}}$} \\
\cline { 2 - 6 } & PC-3M & NCI-H460 & SF-268 & MCF-7 & MDA-MB-231 \\
\hline $\mathbf{1 2}$ & $1.65 \pm 0.33$ & $1.06 \pm 0.03$ & $0.96 \pm 0.08$ & $>5$ & $1.72 \pm 0.27$ \\
$\mathbf{1 3}$ & $1.03 \pm 0.08$ & $0.22 \pm 0.02$ & $0.43 \pm 0.06$ & $1.44 \pm 0.26$ & $1.01 \pm 0.08$ \\
$\mathbf{1 4}$ & $1.53 \pm 0.12$ & $1.51 \pm 0.16$ & $1.31 \pm 0.08$ & $>5$ & $1.32 \pm 0.13$ \\
doxorubicin & $0.25 \pm 0.02$ & $0.05 \pm 0.01$ & $0.45 \pm 0.07$ & $0.32 \pm 0.09$ & $0.67 \pm 0.11$
\end{tabular}

\footnotetext{
${ }^{a}$ Results are expressed as $\mathrm{IC}_{50}$ value \pm standard deviation in $\mu \mathrm{M}$. Doxorubicin and DMSO were used as positive and negative controls.

${ }^{\mathrm{b}}$ Cell lines used: PC-3M = metastatic human prostate adenocarcinoma; NCI-H460 = human non-small cell lung cancer; SF-268 = human CNS glioma; MCF-7 = human breast adenocarcinoma; MDA-MB-231 = metastatic human breast adenocarcinoma.
} 
Xylaguaianols A-D, isocadinanol A, and 9-hydroxyxylarone, together with several known sesquiterpenes and cytochalasins were encountered in Xylaria sp. NC1214, a fungal endophyte of the moss Hypnum sp. Cytochalasin D showed significant cytotoxicity against five cancer cell lines. Cytochalasins C and Q exhibited moderate, but selective cytotoxicity.

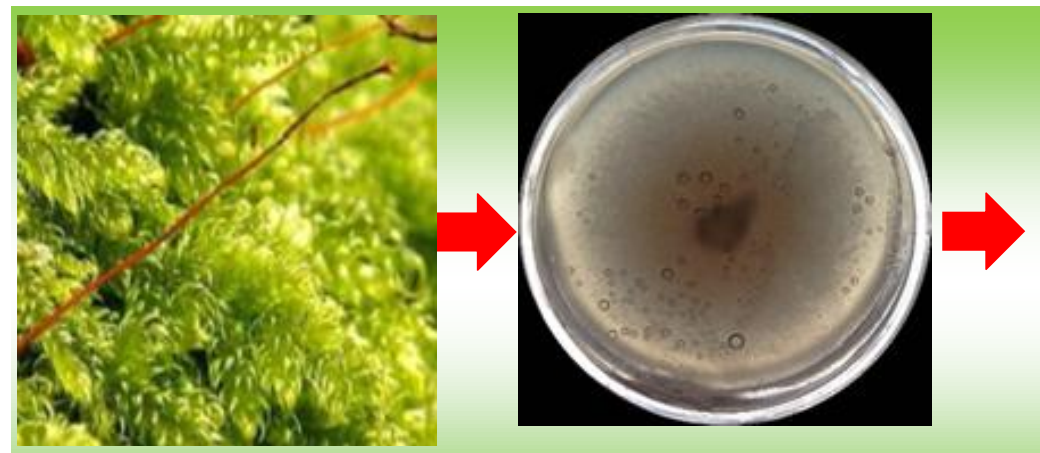

Hypnum sp.

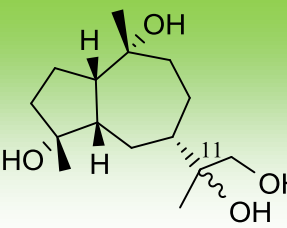

Xylaguaianol $\mathrm{A}\left(11 R^{*}\right)$ Xylaguaianol B (11S*)

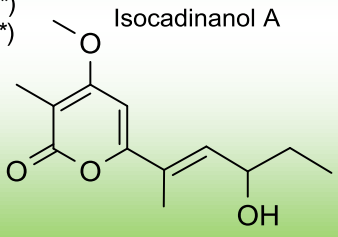

9-Hydroxyxylarone 